\title{
アパタイトセラミックスのプロトン導電性に及ぼす イットリウム固溶の影響
}

\author{
大和田 仁・山下仁大・梅 垣高士・金澤 孝 文
}

(東京都立大学工学部工業化学教室, 158 東京都世田谷区深沢 2-1-1)

\section{Influences of Yttrium-Substitution on the Protonic Conduction of Apatite Ceramics}

\author{
Hitoshi OWADA, Kimihiro YAMASHITA, Takao UMEGAKI and Takafumi KANAZAWA \\ (Department of Industrial Chemistry, Faculty of Technology, Tokyo Metropolitan University, ) \\ 2-1-1, Fukasawa, Setagaya-ku, Tokyo 158
}

\begin{abstract}
The influences of yttrium-substitution on the protonic and $O^{2-}$ conduction in ceramic yttrium substituted oxyhydroxyapatites with the formula $\left[\mathrm{Ca}_{10-x} Y_{x}\right]\left(\mathrm{PO}_{4}\right)_{6}\left[(\mathrm{OH})_{2-x-2 y} \mathrm{O}_{x+y} \square_{y}\right](\mathrm{YHAp}(x))$ were studied. YHAp $(0.65)$ showed the highest value of conductivity $\left(5 \times 10^{-4} \mathrm{~S} / \mathrm{cm}\right)$. This result suggests that the introduction of $\mathrm{O}^{2-}$ and vacancies into $\mathrm{OH}$ sites changed the conduction mechanism. Specimens without $\mathrm{OH}^{-}$, e.g. $Y H A p(1.0)$ indicated $\mathrm{O}^{2-}$ conduction, while protonic conduction was observed in the $Y H A p(x)$ samples with $x<0.8$. Especially, $Y H A p(0.4)$ and $Y H A p(0.65)$, with the remaining $O H^{-}$ of more than 0.5 on the $O H$ sites, were purely protonic conductor. These results suggest that the variation of the amounts of $\mathrm{OH}^{-}, \mathrm{O}^{2-}$ and $\square$ will be attributable to the change in the conduction mechanism. Because of the rapid response of YHAp (0.65) to the change in the partial pressure of $\mathrm{H}_{2}$, YHAp can be expected to be applicable to high temperature fuel cells.
\end{abstract}

[Received May 26, 1989; Accepted June 23, 1989]

Key-words : Yttrium-substitution, Protonic conductor, Apatite ceramics, Oxyhydroxyapatite, Fuel cell

\section{1. 緒言}

生体硬組織の代替材料としての研究が広く行われてい る水酸アパタイト $\left(\mathrm{Ca}_{10}\left(\mathrm{PO}_{4}\right)_{6}(\mathrm{OH})_{2}, \mathrm{HAp}\right)$ は、近年 各種アルコールガス ${ }^{1), 2)}$, 炭酸ガス ${ }^{3)}$, 水蒸気(1), 等のガ スセンサーなど, 電子材料としての研究も行われている. また， $1000^{\circ} \mathrm{C}$ 以上でも構造中の $\mathrm{OH}^{-}$が安定に存在する 特徵から、高温プロトン導電性が期待され，水酸素燃料 電池の隔壁材などへの応用が考えられる.

燃料電池材として使用する場合, 高導電性であり, か つ広い領域でプロトン導電性を示すことが必要であると 考えられる. 現在知られている高温プロトン導電体の代 表的な例として $\mathrm{Sr}-\mathrm{Ce}-\mathrm{M}-\mathrm{O}$ 系酸化物 $(\mathrm{M}=\mathrm{Sc}, \mathrm{Yb} \ldots)$ があるが, プロトン電導を示す水素分圧領域が狭く, 雾 囲気によってはホール電導を示すことが知られてい $3^{5), 6)}$. HAp の電荷担体は, その構造上, $\mathrm{OH}^{-}$, プロト ン, $\mathrm{O}^{2-}$ のいずれかであり，微構造を制御することで純 粋なプロトン導電体を得ることが可能と考えた.

著者らはこれまでに, HAp 中の $\mathrm{Ca}^{2+}$ の一部を希土類 イオンで置換することで，主な導電パスと考えられる $\mathrm{OH}$ サイトに欠陥又は $\mathrm{O}^{2-}$ を導入し, 高温でも安定なオ キシ HAp を合成した ${ }^{7)}$. また, 希土類固溶アパタイト セラミックスでは組成の変化に伴い, 電導度, 電導の 活性化エネルギーが大きく変化した。このことから, 導 電メカニズムに変化が生じ, 複数の電荷担体の存在の可
能性があることを報告した ${ }^{8) ~ 10)}$. 更に，最も高い導電性 を示した $\left[\mathrm{Ca}_{9.35} \mathrm{Y}_{0.65}\right]\left(\mathrm{PO}_{4}\right)_{6}\left[(\mathrm{OH})_{0.7} \mathrm{O}_{0.9} \square_{0.4}\right]$ におい てプロトン電導を確認し, 報告した ${ }^{11)}$. 本報では, イッ トリウム固溶アパタイトセラミックスのプロトン及び $\mathrm{O}^{2-}$ イオン輸率の変化と, 高温型水酸素燃料電池等への 応用について検討を加えた。

\section{2. 実験}

\section{1 試料の合成と焼結}

イットリウム固溶 HAp (YHAp) 粉末の合成は, Ca $\left(\mathrm{NO}_{3}\right)_{2}, \mathrm{Y}\left(\mathrm{NO}_{3}\right)_{3}$ 溶液 $(\mathrm{Ca}: \mathrm{Y}=10-x: x)$ 及び $\left(\mathrm{NH}_{4}\right)_{2} \mathrm{HPO}_{4}$ 溶液を原料として, 既報 ${ }^{7), 8}$ の湿式法に よって行った。得られた粉末を大気中 $800^{\circ} \mathrm{C} て ゙$ 仮焼し

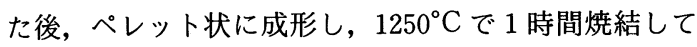
試料焼結体（以後試料とする）を得た。焼結は，高温で の分解によって $\alpha$-TCP $\left(\mathrm{Ca}_{3}\left(\mathrm{PO}_{4}\right)_{2}\right)$ が生成すること を防ぐため, 水蒸気気流中で行った.

\section{2 試料の分析}

試料の密度はトルエンを浸液とし, アルキメデス法に よって測定した. イットリウムの固溶による微構造の変 化を調べるために, 各試料について粉末 X 線回折 (XRD)，KBr 法によるIR 測定を行った. XRD の結 果からアパタイト相の確認, 格子定数の決定を行った. 各試料中の $\mathrm{OH}^{-}$量は, $\mathrm{HAp}$ とフッ素アパタイトとの混 


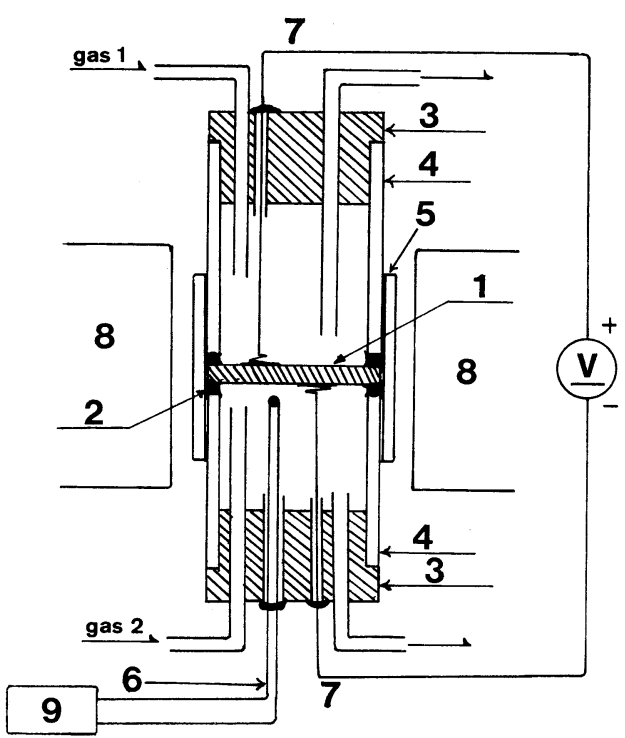

Fig. 1. An assembly for gas concentration cell. 1: YHAp sample, $2:$ Glass O-ring, $3:$ Stainless steel sealing, $4:$ Mullite tube, $5: \mathrm{SiO}_{2}$ glass tube, $6:$ Thermocouple, $7:$ Pt wire, $8:$ Heater, $9:$ Temperature controller

合物を標準に用い， $\mathrm{OH}$ 伸縮振動 $\left(3570 \mathrm{~cm}^{-1}\right)$ の $\mathrm{OH}^{-}$ 量に対する検量線を作成し，各試料の吸収強度をこれと 比較することによって準定量分析した ${ }^{11)}$.

\section{3 電導度の測定}

電導度測定には, 理論密度の $94 \%$ 以上の試料を用い た. 試料研磨面に白金ペーストを電極として焼付け, YHP $4192 \mathrm{~A}$ を用いて, $600^{\circ} \sim 900^{\circ} \mathrm{C}$ 大気中で交流二端 子法で測定した. 試料の抵抗值は $13 \mathrm{MHz} \sim 5 \mathrm{~Hz}$ の複素 インピーダンスダイアグラムの実軸との交点から計算し $た^{11)}$.

\section{4 濃淡電池法によるイオン輸率の測定}

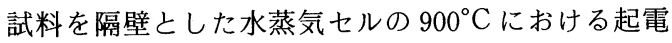
力測定で，生じた起電力の極性から電導の電荷担体を調 ベた11).プロトン及び酸素イオン輸率を求めるために, 各試料を隔壁とした $\mathrm{H}_{2}$ ガス及び $\mathrm{O}_{2}$ ガス濃淡電池の起 電力を測定した. 測定には図 1 に示す装置を用い, gas 1 , gas 2 に送り込むガスの水素, 酸素分圧を変化させたと きの各起電力を読みとった. プロトン輸率は, 対数水素 分圧比 vs. 起電力直線の傾きと Nernst 式より求めた理 論直線のそれとを比較して求めた. 酸素イオン輸率の測 定は, プロトン輸率が 1.0 でない試料について行った。

\section{3. 結果及び考察}

\section{1 試料の分析結果}

XRD の結果から各試料は HAp 単一相であることを 確認した. また, 格子定数は, イットリウムの増加とと

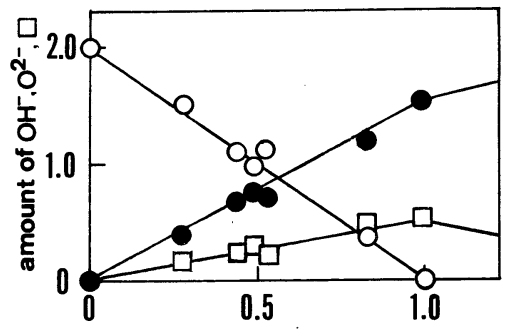

Fig. 2. Change in the amounts of $\mathrm{OH}^{-}, \mathrm{O}^{2-}$ and $\mathrm{OH}$ vacancies with $\mathrm{Y}$ content expressed by $x$ in the formula $\left[\mathrm{Ca}_{10-x} \mathrm{Y}_{x}\right]\left(\mathrm{PO}_{4}\right)_{6}\left[(\mathrm{OH})_{2-x-2 y} \mathrm{O}_{x+y} \square_{y}\right]$.

$\mathrm{O}: \mathrm{OH}^{-}, \mathrm{O}: \mathrm{O}^{2-}, \square:$ vacancy

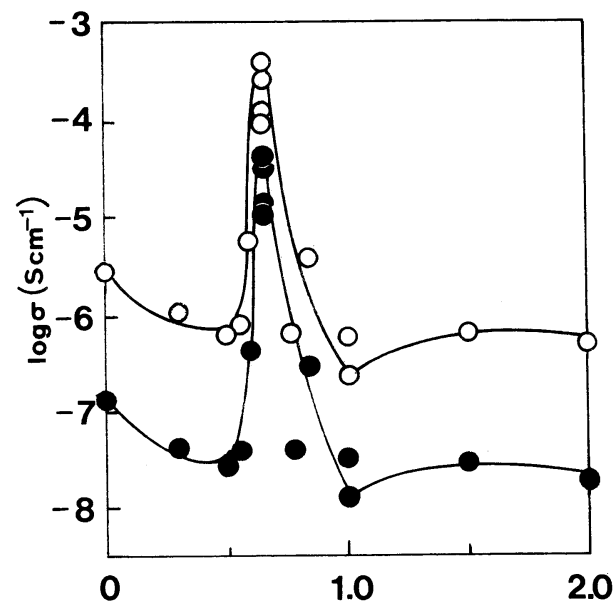

Fig. 3. Dependence of electrical conductivity of YHAp's on the yttrium concentration $x$ at $900^{\circ} \mathrm{C}(\mathrm{O})$ and $700^{\circ} \mathrm{C}(\mathbf{O})$.

もに $a, c$ 両軸ともに減少し, 著者らのこれまでの研 究7) 11) と一致した. また, 試料中のイットリウムの固溶 量は,これまでの蛍光 $\mathrm{X}$ 線を用いた定量の結果 ${ }^{8) ~ 11)}$ から, 原料組成と等しいものと判断した.

IR の結果, YHAp では $\mathrm{OH}$ サイトに $\mathrm{O}^{2-}$ が導入され たことによる， $1010 \mathrm{~cm}^{-1}$ のショルダー ${ }^{12)}$ が観察され， 各試料ともオキシ HAp となっていることが確認され た. $\mathrm{OH}$ 伸縮振動の吸収はイットリウムの増加に伴って 減少し, 試料中の $\mathrm{OH}^{-}$量が減少していることがわかっ た. 特に $\mathrm{Y} /(\mathrm{Ca}+\mathrm{Y}) \geqq 0.1$ では $\mathrm{OH}$ 伸縮振動は観察さ れなかった。したがって, 試料はイットリウムの固溶に 伴って $\mathrm{OH}^{-}$の一部を $\mathrm{O}^{2-}$ で置換し, 更に一部が脱水し

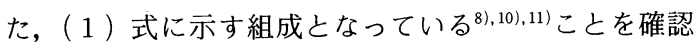
した.

$$
\left[\mathrm{Ca}_{10-x} \mathrm{Y}_{x}\right]\left(\mathrm{PO}_{4}\right)_{6}\left[(\mathrm{OH})_{2-x-2 y} \mathrm{O}_{x+y} \square_{y}\right]
$$

以下, $\mathrm{Y} /(\mathrm{Ca}+\mathrm{Y})=x / 10$ となる $\mathrm{YHAp}$ 試料を YHAp $(x)$ とする.

$\mathrm{OH}^{-}$量を定量したところ, 組成の変化に伴って図 2 のように変化した. イットリウム固溶量の増加に伴って 


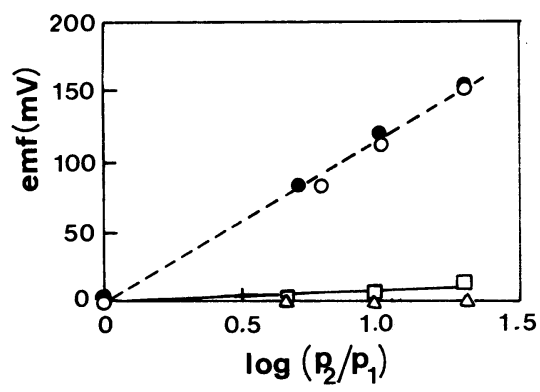

Fig. 4. Emf of the $\mathrm{H}_{2}$ gas concentration cells as functions of the ratio of partial hydrogen pressure (log $\left.\left(P_{2} / P_{1}\right)\right)$.

$\bigcirc:$ YHAp (0.65), : YHAp (0.4), $\square$ : YHAp (0.8), $\triangle:$ YHAp (1.0),

..- : calculated by Nernst's Equation

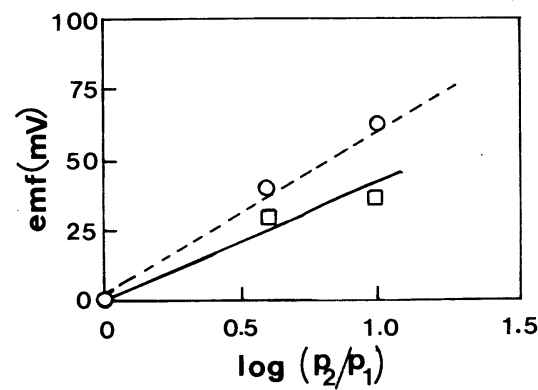

Fig. 5. Emf of the $\mathrm{O}_{2}$ gas concentration cells using YHAp (0.8) ( $\square$ ) and YHAp (1.0) (O) as functions of the ratio of partial oxygen pressure. ... : calculated value

$\mathrm{OH}^{-}$量が減少し, 組成式中の $x \geqq 1.0$ では $\mathrm{OH}^{-}$が存在 せず, $\mathrm{OH}$ サイトは $\mathrm{O}^{2-}$ と欠陥によって占められていた. アパタイトの電気電導には, $\mathrm{OH}$ サイトが大きく寄与し ている ${ }^{13)}$ ので, イットリウムの固溶によって $\mathrm{OH}^{-}$量, $\mathrm{O}^{2-}$ 量を連続的に変化させることで, 導電性・電導入力 ニズムの変化を制御することが可能であると考えられ る ${ }^{8) ~ 11)}$. 特に後述 (3.2 節) のとおり, 本研究に用いた YHAp では $\mathrm{OH}$ サイトの $\mathrm{OH}^{-}$量の変化によって, 電荷 担体が変化するので，イットリウムの固溶量を制御する ことで，電荷担体の異なった試料を得ることが可能とな る.

\section{2 導電性及びイオン輸率の変化}

各試料の組成と, $900^{\circ} \mathrm{C}$ 及び $700^{\circ} \mathrm{C}$ での電導度との 関係を図 3 に示す，試料の導電性は，イットリウムの固 溶量の変化に伴って変化し，特に組成式中の $x=0.65$ 付近の組成で高い導電性 $\left(900^{\circ} \mathrm{C}\right.$ において $5 \times 10^{-4}$ $\mathrm{S} / \mathrm{cm})$ を示した。また，この組成での電導の活性化工 ネルギーは他の組成のそれに比べて, 小さい值 $(1.0 \mathrm{eV})$ を示した ${ }^{8), 11)}$. これらの事実は, 試料の組成変化に伴っ て電導のメカニズムに変化が生じていることを示唆して いる. 水蒸気セルの起電力測定から, YHAp (0.65) で
Table 1. Transport numbers of $\mathrm{H}^{+}$and $\mathrm{O}^{2-}$ of the samples.

\begin{tabular}{|l|l|l|}
\hline & $\mathbf{t}_{\mathrm{H}_{2}}$ & $\mathbf{t}_{\mathrm{O}_{2}}$ \\
\hline YHAp(0.4) & 1.0 & --- \\
YHAp(0.65) & 1.0 & -- \\
YHAp(0.8) & 0.1 & 0.7 \\
YHAp(1.0) & 0.0 & 1.0 \\
\hline
\end{tabular}

はプロトン電導, YHAp (1.0) ではプロトン以外によ

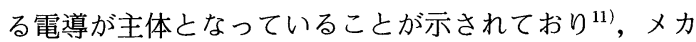
ニズムの変化を裏付けている. また, HAp では, 導電 性に試料の部分脱水によると考えられる経時変化が観察 され, 変化の途中の段階では, YHAp (0.65) とほぼ等 しい值を示した ${ }^{14)}$.これは, $\mathrm{OH}$ サイトの状態の変化が ごく微小でも, その導電性に大きい変化を与えることを 示している.

各試料を隔壁とし, 図 1 の gas 1 に $5 \% \mathrm{H}_{2}+95 \% \mathrm{~N}_{2}$ ガス, gas 2 に $\mathrm{H}_{2}$ 濃度を制御した水素十窒素混合気を 共に $40 \mathrm{ml} / \mathrm{min}$ で流通させた水素ガス濃淡電池の, $900^{\circ} \mathrm{C}$ における分圧比と起電力の関係を図 4 に示す. $\mathrm{OH}$ サイトの $\mathrm{OH}^{-}$量 $\geqq 0.5$ である $\mathrm{YHAp}(0.4)$ と YHAp (0.65) の起電力は, 点線で示した理論起電力と 等しかった. しかし，イットリウムの固溶量が多く, $\mathrm{OH}$ サイトが $\mathrm{O}^{2-}$ と欠陥によって占められていると考え られるYHAp (0.8) 及び YHAp (1.0) では, 生じた 起電力は理論起電力の $10 \%$ 以下であった。 図 5 に YHAp (0.8), YHAp (1.0) の酸素ガス濃淡電池の分 圧比と起電力の関係を示す. 両試料について理論起電力 に近い値を観察した. 表 1 に各試料のプロトン及び酸素 イオン輸率を示す. YHAp (0.8), YHAp (1.0) で, プロトン輸率が低いのは, 図 2 に示すように $\mathrm{OH}$ 量が 少なく, また $\mathrm{OH}$ サイトの欠陥が増し, プロトンホッ ピング15)等のプロトンの移動が起こりにくい状態となっ ているためであると考えられる．逆に， $c$ 軸方向に $\mathrm{O}^{2-}$ と欠陥が連なっていることで $\mathrm{O}^{2-}$ イオンの拡散がより 起こりやすい状態となるため, 高い $\mathrm{O}^{2-}$ イオン輸率を 示すものと考えた。一方, $\mathrm{OH}^{-}$量の多い $\mathrm{YHAp}(0.4)$ 及び $\mathrm{YHAp}(0.65)$ は純粋なプロトン導電体であった。 また，他の研究で HAp の電荷担体はプロトンであるこ とが分かっている ${ }^{14)}$.この要因として， OH サイトに $\mathrm{OH}^{-}$と $\mathrm{O}^{2-}$ が共存する状態では, プロトンの移動が起 こりやすくなることが考えられる.

Maiti らは， $\mathrm{OH}$ サイトに $\mathrm{OH}^{-}$と $\mathrm{F}^{-}$が共存する系に おいて, $\mathrm{OH}: \mathrm{F}=1: 1$ の組成で, $\mathrm{F}^{-}$によるプロトン の吸引効果によってプロトン電導が起こると報告してい る ${ }^{15)}$. 図 2 から分かるように, YHAp (0.65) 付近の組 成域で $\mathrm{OH}$ サイト中の $\mathrm{O}^{2-}: \mathrm{OH}^{-}$はほぼ $1: 1$ であり， 


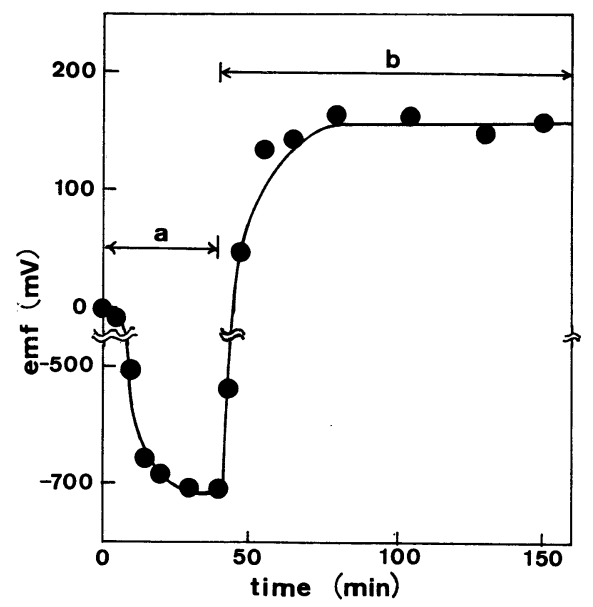

Fig. 6. Response characteristic of the $\mathrm{H}_{2}$ gas cell using YHAp (0.65) to the change of atmosphere.

(a) gas $1-5 \% \mathrm{H}_{2}+95 \% \mathrm{~N}_{2}$ : gas 2-dry $\mathrm{N}_{2}$,

(b) gas $1-5 \% \mathrm{H}_{2}+95 \% \mathrm{~N}_{2}$ : gas 2-dry $\mathrm{H}_{2}$

上記の $\mathrm{F}^{-}-\mathrm{OH}^{-}$系と同様に, $\mathrm{O}^{2-}$ によるプロトンの吸 引効果が考えられ，これが高い導電性を示す要因の一つ であると考えられる.

YHAp (0.65) 試料を隔壁とした水素ガス濃淡電池で, $900^{\circ} \mathrm{C}$ において gas 1, gas 2 のガスを (1) Air : Air, (2) $5 \% \mathrm{H}_{2}+95 \% \mathrm{~N}_{2}: \mathrm{N}_{2}$, (3) $5 \% \mathrm{H}_{2}+95 \% \mathrm{~N}_{2}: \mathrm{H}_{2}$ の順に変 化させたときの応答を図 6 に示す. セル中のガスが完全 に交換されるまでに必要な時間等を考慮すると, 分圧変 化に対して迅速な応答（ガス変更から約 $10 \mathrm{~min}$ ) を示 していると考えられる.

アパタイトは, 焼結の容易さ・製造コスト等, 種々の 利点を有しており, 特に YHAp (0.65) は高導電性プ ロトン導電体であり, 水素分圧の変化に対して高い応答 性を示すことから, 水酸素燃料電池隔壁材, 高温水素セ ンサー等への応用が期待される.

\section{4. 総 括}

濃淡電池法によって, イットリウム固溶 HAp のプロ トン及び酸素イオン輸率を測定し, 固溶化による微構造 の変化と, 導電性の変化の関係について考察した. その 結果, 以下のことが明らかとなり，アパタイトセラミッ クスの高温型水酸素然料電池材への応用の可能性が示さ
れた。

（1） $\mathrm{OH}$ サイトに $\mathrm{OH}^{-}$が十分に存在する試料は, プロトン導電性を示した.

(2) $\mathrm{OH}$ サイトが $\mathrm{O}^{2-}$ と欠陥で占められている試料 は, 酸素イオン電導を示した。

（3）（1）と（2）の中間組成の試料は, プロトン, 酸素イオンの混合イオン導電体であった。

(4) YHAp (0.65) を用いた水素濃淡電池は分圧変 化に対して高い応答性を示した。

謝辞 本研究の遂行に当たり，その一部を平成元年度東 京都立大学特定研究費 (課題「電子機能薄膜の開発に関する基 礎研究」)によった.

濃淡電池実験装置の組み立てに当たって，七ラミックスと試 料の封着法について, 有益な助言を頂いた名古屋大学工学部・ 岩原弘育教授，並びに封着ガラスサンプルの提供を頂いた日本 電気硝子 (株) に対し謝意を表します。

\section{文献}

1) Y. Komine and K. Sato, FC Report, 1 [10], 4-10 (1983).

2) 小峰義治, 第 1 回アパタイト研究会講演予稿集 (1985) p. 51 .

3）永井正幸, 河合信行, 岩永泰成, 鶴田稔史, 村田 裕, 西野 忠, 窯業協会昭和 60 年年会講演予稿集 (1985) p. 411.

4) H. Owada, K. Yamashita, T. Umegaki, T. Kanazawa and M. Nagai, Solid State Ionics (1989) in press.

5) H. Iwahara, T. Esaka, H. Uchida and N. Maeda, Solid State Ionics, 3/4, 359-63 (1981).

6) H. Uchida, N. Maeda and H. Iwahara, Solid State Ionics, 11, 117-22 (1983).

7) K. Yamashita, T. Umegaki, H. Nakagawa, H. Owada and T. Kanazawa, J. Am. Ceram. Soc., 69, 590-94 (1986).

8) H. Owada, K. Yamashita, T. Umegaki, T. Kanazawa and M. Nagai, Yogyo-Kyokai-Shi, 94, 837-41 (1986).

9) K. Yamashita, H. Owada, T. Umegaki and T. Kanazawa, Memoirs of Faculty of Technology of Tokyo Metropolitan University, 36, 3779-84 (1987).

10) K. Yamashita, H. Owada, T. Umegaki, T. Kanazawa and T. Futagami, Solid State Ionics, 28-30, 660-63 (1988).

11）大和田 仁, 山下仁大, 梅垣高士, 金澤孝文, 石高亡石灰, No. 217, 7-12 (1988).

12) J. C. Trombe and G. Montel, J. Inorg. Nucl. Chem., 40, 15-31 (1978)

13) T. Takahashi, S. Tanase and O. Yamamoto, Electrochimica Acta, 23, 369-73 (1978).

14) K. Yamashita et al., in preparation.

15) G. C. Maiti and F. Freund, J. Chem. Soc., Dalton Trans., 949-55 (1981). 